Supporting Information Available For:

\title{
Total synthesis of psammaplysenes $A$ and $B$, naturally occurring inhibitors of FOXO1a nuclear export
}

Savvas N. Georgiades and Jon Clardy

Department of Biological Chemistry and Molecular Pharmacology, Harvard Medical School, Boston, MA 02115

jon_clardy@hms.harvard.edu

\section{Table of contents}

- General methods $\quad$ Page S-2

- Solvents and materials $\quad$ Page S-2

- Experimental procedures/characterization data Page S-3

- ${ }^{1} \mathrm{H}-\mathrm{NMR}$ spectra of psammaplysenes A and B Page S-23 
General methods: NMR spectra were recorded on a Varian Inova-500 NMR spectrometer (at $500 \mathrm{MHz}$ for ${ }^{1} \mathrm{H}$ and $126 \mathrm{MHz}$ with complete proton decoupling for $\left.{ }^{13} \mathrm{C}\right)$. NMR data were collected at $25{ }^{\circ} \mathrm{C}$. Chemical shifts $\delta$ are reported in parts per million (ppm) downfield relative to tetramethylsilane ( $\delta=0.00$ ), using the solvent residual peak in each case as a reference.

Mass spectra were obtained on a Waters Alliance LC-MS system which is a combination of a Micromass Platform LCZ mass spectrometer (using ESI), a Waters 2960 separation module and a Waters 996 photodiode array detector.

Flash chromatography was performed using Silica Gel 60 (particle size 0.040-0.063 mm) from Fisher Scientific.

For those reactions requiring an inert atmosphere, the sealed reaction vessels/flasks containing the solids were initially purged with argon before any additions of liquids and were kept under argon at balloon pressure throughout the reaction.

Solvents and materials: All organic solvents used for reactions in this study were anhydrous or redistilled (unless otherwise stated) and came in Sure/Seal ${ }^{\mathrm{TM}}$ bottles, packaged under nitrogen. All solvents and chemicals were purchased from Sigma-Aldrich, with the exception of $\operatorname{Pd}\left(\mathrm{Ph}_{3} \mathrm{P}\right)_{4}$ which was purchased from Strem Chemicals. 


\section{Experimental procedures/characterization data:}

\section{$N$-bromo-tert-butylamine.}

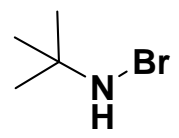

Procedure: $25 \mathrm{~mL}$ of a $\mathrm{NaOH} 2 \mathrm{M}$ aqueous solution $(50 \mathrm{mmol})$ were transferred to a round-bottom flask, along with $5.28 \mathrm{~mL}$ (50 mmol, 1 equiv.) of tert-butylamine. The mixture was stirred at room temperature for 5 minutes and subsequently cooled at $0{ }^{\circ} \mathrm{C}$. Under vigorous stirring, $2.57 \mathrm{~mL}$ (50 mmol, 1 equiv.) of $\mathrm{Br}_{2}$ were added dropwise at a slow rate. The reaction was then allowed to proceed for $30-45$ more minutes at $0{ }^{\circ} \mathrm{C}$. The mixture was diluted with $\mathrm{H}_{2} \mathrm{O}$ and extracted twice with ethyl ether. After drying the combined organic phase over $\mathrm{MgSO}_{4}$, the ether was removed under vacuum to afford $N$-bromo-tert-butylamine as an orange oil. $7.00 \mathrm{~g} \mathrm{(46} \mathrm{mmol,} \mathrm{92 \% )}$

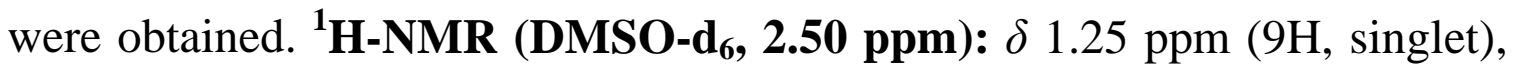
7.73 ppm ( 1H, broad singlet). ${ }^{13}$ C-NMR (DMSO-d 6 , 39.43 ppm): $\delta 27.09$ ppm, 50.92 ppm.

\section{2,6-Dibromo-4-iodophenol (7).}

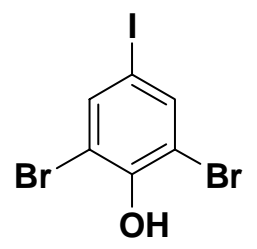

Procedure: A round-bottom flask was charged with $4.51 \mathrm{~g}$ (20.5 mmol) of 4-iodophenol (6). These were dissolved in $45 \mathrm{~mL}$ of 1,2-dichlorobenzene and cooled at $0{ }^{\circ} \mathrm{C}$. Under continuous stirring, $6.54 \mathrm{~g}$ (43 mmol, 2.1 equiv.) 
of freshly prepared $N$-bromo-tert-butylamine dissolved in $20 \mathrm{~mL}$ of $1,2-$ dichlorobenzene were added dropwise through an addition funnel at a very slow rate. The reaction was then allowed to proceed for 30-45 more minutes at $0{ }^{\circ} \mathrm{C}$, during which 7 precipitated out as a white solid. The reaction mixture was filtered through a Buchner funnel while still cold and the solid was washed with a small quantity of cold 1,2-dichlorobenzene and allowed to dry under vacuum. This was followed by extensive drying on a lyophilizer, after which LC-MS and NMR showed the product to be free of impurities. The solid weighted $6.47 \mathrm{~g}$ (17.2 mmol, 84\%). ${ }^{\mathbf{1}} \mathbf{H}-\mathbf{N M R}\left(\mathbf{C D C l}_{\mathbf{3}}\right.$, 7.26 ppm): $\delta 5.88$ ppm ( 1H, singlet), 7.68 ppm (2H, singlet). ${ }^{13} \mathbf{C}-\mathbf{N M R}$ (CDCl $\mathbf{3}, \mathbf{7 7 . 0} \mathbf{p p m}): \delta 81.59$ ppm, 110.88 ppm, 139.53 ppm, 149.48 ppm. MS (ESI): $m / z(\mathrm{M}-\mathrm{H})^{-}-$-found: 374.73, (M-H)-c-calculated: 374.75.

\section{3-(2,6-Dibromo-4-iodophenoxy)- $N, N$-dimethyl-propylamine (8).}

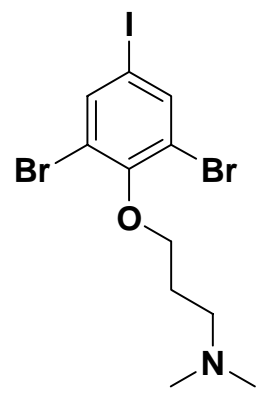

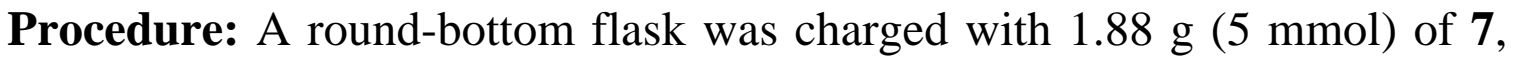
$1.03 \mathrm{~g}$ (6.5 mmol, 1.3 equiv.) of 1-chloro-3-dimethylaminopropane hydrochloride, $4.07 \mathrm{~g}$ (12.5 mmol, 2.5 equiv.) of $\mathrm{Cs}_{2} \mathrm{CO}_{3}$ and $0.19 \mathrm{~g}$ (1.25 mmol, 0.25 equiv.) of $\mathrm{NaI}$. $50 \mathrm{~mL}$ of $\mathrm{CH}_{3} \mathrm{CN}$ were added and the mixture was stirred at $65{ }^{\circ} \mathrm{C}$ under argon for $12 \mathrm{~h}$. It was then cooled down and filtered to remove inorganic solids. The solvent was removed under vacuum and the crude product was redissolved in $\mathrm{CH}_{2} \mathrm{Cl}_{2}$, applied to a silica column 
and eluted with 9:1 v/v $\mathrm{CH}_{2} \mathrm{Cl}_{2}-\mathrm{CH}_{3} \mathrm{OH}$. Purification afforded $1.67 \mathrm{~g}$ (3.6 mmol, $72 \%$ ) of $\mathbf{8}$ as a white solid. ${ }^{1} \mathbf{H}-\mathbf{N M R}\left(\mathbf{C D C l}_{3}, \mathbf{7 . 2 6} \mathbf{~ p p m ) :} \delta 2.12 \mathrm{ppm}\right.$ (2H, triple-triplet appearing as a quintet), $2.39 \mathrm{ppm}$ (6H, singlet), $2.68 \mathrm{ppm}$ (2H, triplet, $J=8.1 \mathrm{~Hz}$ ), 4.05 ppm (2H, triplet, $J=5.5 \mathrm{~Hz}), 7.81 \mathrm{ppm}(2 \mathrm{H}$, singlet). ${ }^{13} \mathbf{C}-\mathbf{N M R}\left(\mathbf{C D C l}_{3}, \mathbf{7 7 . 0} \mathbf{p p m}\right): \delta 27.48 \mathrm{ppm}, 45.12 \mathrm{ppm}, 56.04$ ppm, 71.43 ppm, 87.81 ppm, 119.63 ppm, 140.69 ppm, 155.62 ppm. MS (ESI): $m / z(\mathrm{M}+\mathrm{H})^{+}$-found: 461.89, $(\mathrm{M}+\mathrm{H})^{+}$-calculated: 461.86 .

\section{(E)-methyl 3-[3,5-dibromo-4-(3-dimethylamino-propoxy)-phenyl]-} acrylate (9).

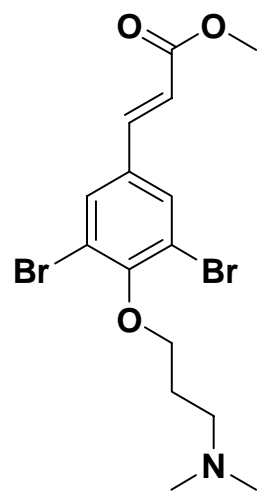

Procedure: A round-bottom flask was charged with $1.39 \mathrm{~g}$ ( $3 \mathrm{mmol})$ of $\mathbf{8}$, $0.17 \mathrm{~g}$ ( $0.75 \mathrm{mmol}, 0.25$ equiv.) of $\mathrm{Pd}(\mathrm{OAc})_{2}, 0.97 \mathrm{~g}$ (3 mmol, 1 equiv.) of $\mathrm{Bu}_{4} \mathrm{NBr}, 0.88 \mathrm{~g}$ (9 mmol, 3 equiv.) of KOAc and a few $4 \AA$ molecular sieves. $22.5 \mathrm{~mL}$ of DMF were added to dissolve the solids, followed by 1.35 $\mathrm{mL}$ (15 mmol, 5 equiv.) of methyl acrylate. The mixture was vigorously agitated on a shaker at room temperature for $8 \mathrm{~h}$ under argon. It was then diluted with ethyl ether and washed once with aqueous $\mathrm{NaHCO}_{3}$ (sat.), once with aqueous $\mathrm{NaCl}$ (sat.) and once with $\mathrm{H}_{2} \mathrm{O}$. After drying the organic phase over $\mathrm{MgSO}_{4}$, the ether was removed under vacuum. The residue was redissolved in $\mathrm{CH}_{2} \mathrm{Cl}_{2}$, applied to a silica column and eluted with 9:1 v/v 
$\mathrm{CH}_{2} \mathrm{Cl}_{2}-\mathrm{CH}_{3} \mathrm{OH}$. Purification afforded $1.09 \mathrm{~g}(2.59 \mathrm{mmol}, 86 \%)$ of 9 as a white waxy solid. ${ }^{1} \mathbf{H}-\mathbf{N M R}\left(\mathbf{C D C l}_{3}, \mathbf{7 . 2 6} \mathbf{~ p p m}\right): \delta 2.06 \mathrm{ppm}(2 \mathrm{H}$, tripletriplet appearing as a quintet), $2.29 \mathrm{ppm}(6 \mathrm{H}$, singlet), $2.58 \mathrm{ppm}(2 \mathrm{H}$, triplet, $J=7.5 \mathrm{~Hz}$ ), $3.79 \mathrm{ppm}$ (3H, singlet), $4.07 \mathrm{ppm}$ (2H, triplet, $J=6.1 \mathrm{~Hz}$ ), 6.34 ppm $(1 \mathrm{H}$, doublet, $J=16.0 \mathrm{~Hz}), 7.48 \mathrm{ppm}(1 \mathrm{H}$, doublet, $J=16.0 \mathrm{~Hz}), 7.64$ ppm (2H, singlet). ${ }^{13} \mathbf{C}-\mathbf{N M R}\left(\mathbf{C D C l}_{3}, \mathbf{7 7 . 0} \mathbf{~ p p m}\right): \delta 28.19$ ppm, 45.43 ppm, 51.95 ppm, 56.24 ppm, 72.04 ppm, 118.89 ppm, 119.54 ppm, 132.01 ppm, 132.96 ppm, 141.52 ppm, 155.01 ppm, 166.95 ppm. MS (ESI): $\mathrm{m} / z$ $(\mathrm{M}+\mathrm{H})^{+}$-found: 420.00, $(\mathrm{M}+\mathrm{H})^{+}$-calculated: 419.98.

(E)-3-[3,5-dibromo-4-(3-dimethylamino-propoxy)-phenyl]-acrylic acid (3).

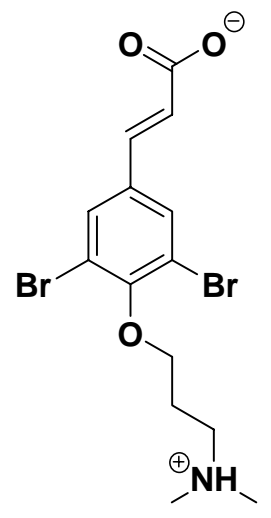

Procedure: A flask was charged with $1.05 \mathrm{~g}(2.5 \mathrm{mmol})$ of 9 and $0.70 \mathrm{~g}$ (12.5 mmol, 5 equiv.) of $\mathrm{KOH}$ as a fine powder. $12 \mathrm{~mL}$ of $\mathrm{CH}_{3} \mathrm{OH}$ and $0.225 \mathrm{~mL}$ (12.5 mmol, 5 equiv.) of $\mathrm{H}_{2} \mathrm{O}$ were added and the solution was vigorously stirred at room temperature for $12 \mathrm{~h}$. The reaction mixture was then concentrated under vacuum, applied directly to a silica column and eluted using $\mathrm{CH}_{2} \mathrm{Cl}_{2}-\mathrm{CH}_{3} \mathrm{OH}$ solvent systems, starting with 9-1 v/v and finishing with $7-3 \mathrm{v} / \mathrm{v}$, all modified with $0.5 \%$ triethylamine. Purification afforded $0.97 \mathrm{~g}$ (2.38 mmol, 95\%) of $\mathbf{3}$ as a white solid. ${ }^{1} \mathbf{H}-\mathbf{N M R}\left(\mathbf{C D}_{\mathbf{3}} \mathbf{O D}\right.$, 
$3.31 \mathrm{ppm}): \delta 2.21 \mathrm{ppm}$ ( $2 \mathrm{H}$, triple-triplet appearing as a quintet), $2.76 \mathrm{ppm}$ (6H, singlet), $3.23 \mathrm{ppm}$ (2H, triplet, $J=7.8 \mathrm{~Hz}$ ), $4.08 \mathrm{ppm}$ (2H, triplet, $J=5.8$ $\mathrm{Hz}), 6.44 \mathrm{ppm}(1 \mathrm{H}$, doublet, $J=15.9 \mathrm{~Hz}), 7.21 \mathrm{ppm}(1 \mathrm{H}$, doublet, $J=15.9$ $\mathrm{Hz}$ ), 7.71 ppm (2H, singlet). ${ }^{13} \mathbf{C}-\mathbf{N M R}$ (CD $\mathbf{C} \mathbf{O D}, 49.05$ ppm): $\delta 27.36 \mathrm{ppm}$, 44.27 ppm, 57.24 ppm, 72.04 ppm, 119.05 ppm, 119.43 ppm, 132.40 ppm, $132.72 \mathrm{ppm}, 142.91 \mathrm{ppm}, 153.70 \mathrm{ppm}, 174.66 \mathrm{ppm}$. MS (ESI): $\mathrm{m} / \mathrm{z}$ $(\mathrm{M}+\mathrm{H})^{+}$-found: 405.95, $(\mathrm{M}+\mathrm{H})^{+}$-calculated: 405.97.

\section{$N$-(3-bromopropyl)-2-nitrobenzene-sulfonamide.}

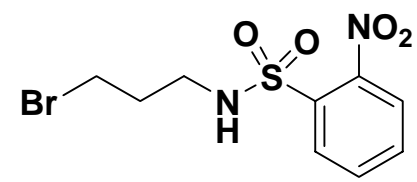

Procedure: A round-bottom flask was charged with $4.38 \mathrm{~g}$ (20 mmol) of 3bromo-propylamine hydrobromide and $5.32 \mathrm{~g}$ ( $24 \mathrm{mmol}, 1.2$ equiv.) of 2nitrobenzene-sulfonyl chloride. $60 \mathrm{~mL}$ of $\mathrm{CH}_{2} \mathrm{Cl}_{2}$ were added and the mixture was cooled at $0{ }^{\circ} \mathrm{C}$. After adding $6.69 \mathrm{~mL}$ (48 mmol, 2.4 equiv.) of triethylamine, the reaction was allowed to proceed at room temperature for 3 h under argon. The solution was then washed once with $1 \mathrm{M}$ aqueous $\mathrm{HCl}$, once with aqueous $\mathrm{NaCl}$ (sat.) and once with $\mathrm{H}_{2} \mathrm{O}$. After drying the organic phase over $\mathrm{MgSO}_{4}$, the $\mathrm{CH}_{2} \mathrm{Cl}_{2}$ was removed under vacuum to afford $5.95 \mathrm{~g}$ (18.4 mmol, 92\%) of $\mathrm{N}$-(3-bromopropyl)-2-nitrobenzene-sulfonamide as a white solid. This was pure by LC-MS and NMR. ${ }^{1} \mathbf{H}-\mathbf{N M R}\left(\mathbf{C D C l}_{3}, \mathbf{7 . 2 6}\right.$ ppm): $\delta 2.10 \mathrm{ppm}$ (2H, triple-triplet appearing as a quintet), $3.25 \mathrm{ppm}(2 \mathrm{H}$, double-triplet appearing as a quartet), $3.44 \mathrm{ppm}(2 \mathrm{H}$, triplet, $J=6.3 \mathrm{~Hz}), 5.46$ ppm (1H, triplet, $J=6.1 \mathrm{~Hz}$ ), 7.75 ppm (2H, two overlapping double-doublets appearing as a multiplet), $7.85 \mathrm{ppm}(1 \mathrm{H}$, doublet, $J=6.8 \mathrm{~Hz}), 8.12 \mathrm{ppm}(1 \mathrm{H}$, doublet, $J=6.8 \mathrm{~Hz}) .{ }^{13} \mathbf{C}-\mathbf{N M R}\left(\mathbf{C D C l}_{3}, \mathbf{7 7 . 0} \mathbf{~ p p m}\right): \delta 29.85$ ppm, 32.32 ppm, 
41.93 ppm, 125.40 ppm, 131.03 ppm, 132.89 ppm, 133.16 ppm, 133.66 ppm, 147.99 ppm. MS (ESI): $m / z \quad(\mathrm{M}+\mathrm{H})^{+}$-found: 322.98, $(\mathrm{M}+\mathrm{H})^{+}-$ calculated: 322.97.

\section{$N$-[3-(2,6-dibromo-4-iodophenoxy)-propyl]-2-nitrobenzene-sulfonamide} (10).

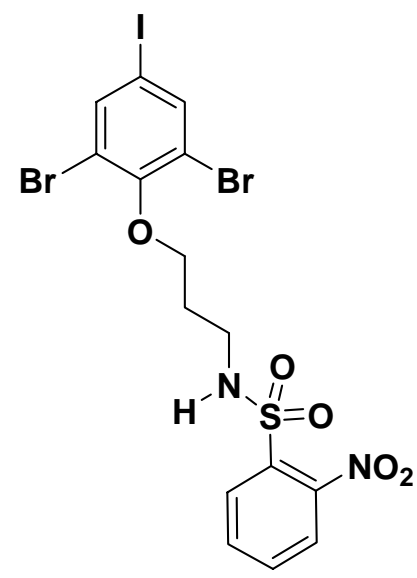

Procedure: A round-bottom flask was charged with $1.13 \mathrm{~g}$ (3 mmol) of 7, $1.26 \mathrm{~g}$ (3.9 mmol, 1.3 equiv.) of Ns-protected 3-bromo-propylamine, $1.47 \mathrm{~g}$ (4.5 mmol, 1.5 equiv.) of $\mathrm{Cs}_{2} \mathrm{CO}_{3}$ and $0.11 \mathrm{~g}(0.75 \mathrm{mmol}, 0.25$ equiv.) of NaI. $25 \mathrm{~mL}$ of $\mathrm{CH}_{3} \mathrm{CN}$ were added and the mixture was stirred at $50{ }^{\circ} \mathrm{C}$ under argon for $6 \mathrm{~h}$. It was then cooled down and filtered to remove inorganic solids. The solvent was removed under vacuum and the sample was redissolved in a small amount of ethyl acetate. It was applied to a silica column and eluted with 2:1 v/v hexane-ethyl acetate. Purification afforded $1.30 \mathrm{~g}$ (2.1 mmol, 70\%) of $\mathbf{1 0}$ as a white solid. ${ }^{\mathbf{1}} \mathbf{H}-\mathbf{N M R}\left(\mathbf{C D C l}_{3}, \mathbf{7 . 2 6}\right.$ ppm): $\delta 2.07 \mathrm{ppm}(2 \mathrm{H}$, triple-triplet appearing as a quintet), $3.46 \mathrm{ppm}(2 \mathrm{H}$, double-triplet appearing as a quartet), $4.02 \mathrm{ppm}(2 \mathrm{H}$, triplet, $J=6.2 \mathrm{~Hz}), 5.77$ ppm (1H, triplet, $J=6.0 \mathrm{~Hz}$ ), $7.74 \mathrm{ppm}(2 \mathrm{H}$, two overlapping double-doublets appearing as a multiplet), $7.79 \mathrm{ppm}(2 \mathrm{H}$, singlet), $7.86 \mathrm{ppm}(1 \mathrm{H}$, doublet, $J=6.9 \mathrm{~Hz}), 8.16 \mathrm{ppm}(1 \mathrm{H}$, doublet, $J=6.9 \mathrm{~Hz}) .{ }^{13} \mathbf{C}-\mathbf{N M R}\left(\mathbf{C D C l}_{3}, \mathbf{7 7 . 0}\right.$ 
ppm): $\delta 29.94$ ppm, 41.28 ppm, 70.63 ppm, 87.92 ppm, 119.11 ppm, 125.45 ppm, 130.91 ppm, 132.90 ppm, 133.08 ppm, 133.56 ppm, 140.75 ppm, $148.22 \mathrm{ppm}, 157.79$ ppm. MS (ESI): $\mathrm{m} / z(\mathrm{M}+\mathrm{H})^{+}$-found: 618.80, $(\mathrm{M}+\mathrm{H})^{+}-$ calculated: 618.81.

\section{$N$-[3-(2,6-dibromo-4-iodophenoxy)-propyl]- $N$-methyl-2-nitrobenzene- sulfonamide (11).}

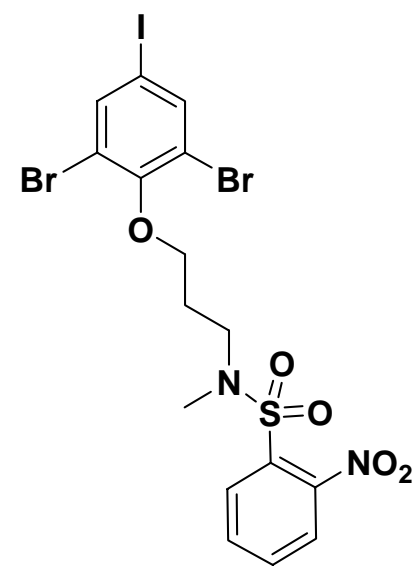

Procedure: A round-bottom flask was charged with $1.24 \mathrm{~g}(2 \mathrm{mmol})$ of $\mathbf{1 0}$ and $1.05 \mathrm{~g}$ ( $4 \mathrm{mmol}$, 2 equiv.) of triphenylphosphine. $4.5 \mathrm{~mL}$ of toluene were added, followed by $0.73 \mathrm{~mL}$ ( $4 \mathrm{mmol}$, 2 equiv.) of DEAD. The mixture was stirred at room temperature for 5 mins under argon before $0.16 \mathrm{~mL}(4 \mathrm{mmol}$, 2 equiv.) of $\mathrm{CH}_{3} \mathrm{OH}$ were slowly syringed in. Stirring continued for 15-20 more minutes. The reaction mixture was then diluted with ethyl ether and washed twice with aqueous $\mathrm{NaCl}$ (sat.) and once with $\mathrm{H}_{2} \mathrm{O}$. After drying the organic phase over $\mathrm{MgSO}_{4}$, most of the ether was removed under vacuum and the concentrated crude sample was applied to a silica column. A 2:1 v/v hexane-ethyl acetate mixture was used for elution. Purification yielded 1.19 g (1.88 mmol, $94 \%)$ of $\mathbf{1 1}$ as a viscous colorless oil. ${ }^{\mathbf{1}} \mathbf{H}-\mathbf{N M R}\left(\mathbf{C D C l}_{3}, \mathbf{7 . 2 6}\right.$ ppm): $\delta 2.16 \mathrm{ppm}(2 \mathrm{H}$, triple-triplet appearing as a quintet), $2.97 \mathrm{ppm}(3 \mathrm{H}$, singlet), $3.53 \mathrm{ppm}(2 \mathrm{H}$, triplet, $J=7.5 \mathrm{~Hz}), 4.02 \mathrm{ppm}(2 \mathrm{H}$, triplet, $J=6.1 \mathrm{~Hz})$, 
$7.62 \mathrm{ppm}(1 \mathrm{H}$, doublet, $J=6.9 \mathrm{~Hz}), 7.68 \mathrm{ppm}(2 \mathrm{H}$, two overlapping doubledoublets appearing as multiplet), $7.80 \mathrm{ppm}(2 \mathrm{H}$, singlet), $8.01 \mathrm{ppm}(1 \mathrm{H}$, doublet, $J=6.9 \mathrm{~Hz}$ ). ${ }^{13} \mathbf{C}-\mathbf{N M R}\left(\mathbf{C D C l}_{\mathbf{3}}, \mathbf{7 7 . 0} \mathbf{~ p p m}\right): \delta 28.48 \mathrm{ppm}, 34.73 \mathrm{ppm}$, 47.80 ppm, 70.86 ppm, 87.57 ppm, 119.12 ppm, 124.03 ppm, 130.83 ppm, 131.47 ppm, 132.13 ppm, 133.48 ppm, 140.63 ppm, 148.16 ppm, 157.62 ppm. MS (ESI): $m / z(\mathrm{M}+\mathrm{H})^{+}$-found: 632.79, $(\mathrm{M}+\mathrm{H})^{+}$-calculated: 632.82.

\section{(E)-methyl 3-\{3,5-dibromo-4-[3-( $N$-methyl-2-nitrophenylsulfonamido)- propoxy]-phenyl\}-acrylate (12).}

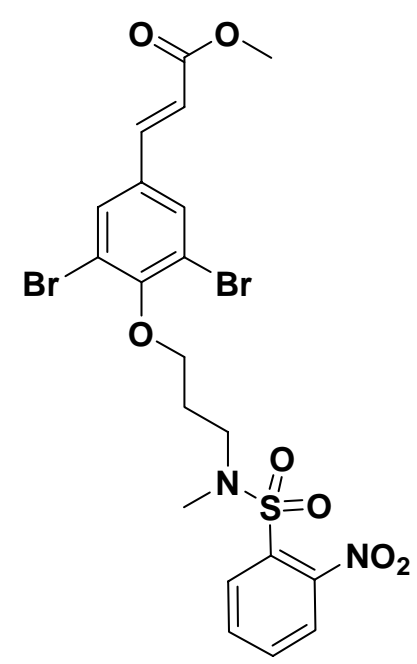

Procedure: A round-bottom flask was charged with $0.95 \mathrm{~g}(1.5 \mathrm{mmol})$ of 11, $0.084 \mathrm{~g}$ ( $0.375 \mathrm{mmol}, 0.25$ equiv.) of $\mathrm{Pd}(\mathrm{OAc})_{2}, 0.48 \mathrm{~g}(1.5 \mathrm{mmol}, 1$ equiv.) of $\mathrm{Bu}_{4} \mathrm{NBr}, 0.44 \mathrm{~g}$ ( $4.5 \mathrm{mmol}, 3$ equiv.) of KOAc and a few $4 \AA$ molecular sieves. $12.5 \mathrm{~mL}$ of DMF were added to dissolve the solids, followed by $0.675 \mathrm{~mL}$ (7.5 mmol, 5 equiv.) of methyl acrylate. The mixture was vigorously agitated on a shaker at room temperature for $8 \mathrm{~h}$ under argon. It was then diluted with ethyl ether and washed once with aqueous $\mathrm{NaHCO}_{3}$ (sat.), once with aqueous $\mathrm{NaCl}$ (sat.) and once with $\mathrm{H}_{2} \mathrm{O}$. After drying the organic phase over $\mathrm{MgSO}_{4}$, most of the ether was removed under 
vacuum and the concentrated crude sample was applied to a silica column and eluted with 1:1 v/v hexane-ethyl acetate. Purification afforded $0.79 \mathrm{~g}$ (1.34 mmol, 89\%) of $\mathbf{1 2}$ as a viscous colorless oil. ${ }^{\mathbf{1}} \mathbf{H}$-NMR $\left(\mathbf{C D C l}_{3}, \mathbf{7 . 2 6}\right.$ ppm): $\delta 2.16 \mathrm{ppm}$ (2H, triple-triplet appearing as a quintet), $2.98 \mathrm{ppm}(3 \mathrm{H}$, singlet), $3.56 \mathrm{ppm}$ (2H, triplet, $J=7.5 \mathrm{~Hz}$ ), $3.79 \mathrm{ppm}$ (3H, singlet), $4.06 \mathrm{ppm}$ (2H, triplet, $J=6.1 \mathrm{~Hz}), 6.36 \mathrm{ppm}(1 \mathrm{H}$, doublet, $J=15.9 \mathrm{~Hz}), 7.47 \mathrm{ppm}(1 \mathrm{H}$, doublet, $J=15.9 \mathrm{~Hz}), 7.62 \mathrm{ppm}(1 \mathrm{H}$, doublet, $J=7.1 \mathrm{~Hz}), 7.64 \mathrm{ppm}(2 \mathrm{H}$, singlet), $7.70 \mathrm{ppm}(2 \mathrm{H}$, two overlapping double-doublets appearing as a multiplet), $8.01 \mathrm{ppm}(1 \mathrm{H}$, doublet, $J=7.1 \mathrm{~Hz}) .{ }^{13} \mathbf{C}-\mathbf{N M R}\left(\mathbf{C D C l}_{3}, \mathbf{7 7 . 0}\right.$ ppm): $\delta 28.55$ ppm, 34.76 ppm, 47.43 ppm, 51.92 ppm, 70.83 ppm, 118.68 ppm, 119.74 ppm, 124.05 ppm, 130.87 ppm, 131.48 ppm, 131.98 ppm, 132.09 ppm, 133.11 ppm, 133.47 ppm, 141.05 ppm, 148.27 ppm, 154.32 ppm, 166.55 ppm. MS (ESI): $m / z \quad(\mathrm{M}+\mathrm{H})^{+}-$found: 590.98, $(\mathrm{M}+\mathrm{H})^{+}-$ calculated: 590.95 .

(E)-3-\{3,5-dibromo-4-[3-( $N$-methyl-2-nitrophenylsulfonamido)-propoxy] -phenyl\}-acrylic acid (13).

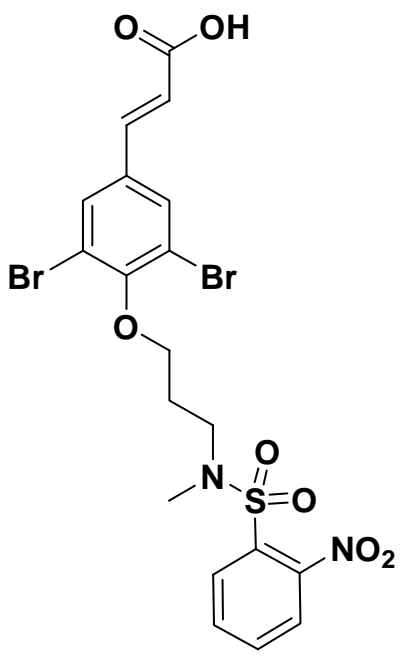


Procedure: A flask was charged with $0.59 \mathrm{~g}(1 \mathrm{mmol})$ of 12 and $0.28 \mathrm{~g}$ (5 mmol, 5 equiv.) of $\mathrm{KOH}$ as a fine powder. $4.5 \mathrm{~mL}$ of $\mathrm{CH}_{3} \mathrm{OH}$ and $0.09 \mathrm{~mL}$ ( 5 mmol, 5 equiv.) of $\mathrm{H}_{2} \mathrm{O}$ were added and the mixture was vigorously stirred at room temperature for $12 \mathrm{~h}$. It was then concentrated under vacuum, applied to a silica column and eluted using $\mathrm{CH}_{2} \mathrm{Cl}_{2}-\mathrm{CH}_{3} \mathrm{OH}$ solvent systems, starting with 9-1 v/v and finishing with $7-3 \mathrm{v} / \mathrm{v}$, all modified with $0.5 \%$ formic acid. Purification afforded $0.55 \mathrm{~g}$ (0.95 mmol, 95\%) of 13 as a white solid. ${ }^{1} \mathbf{H}-\mathbf{N M R}\left(\mathbf{C D C l}_{3}, \mathbf{7} .26 \mathbf{~ p p m}\right): \delta 2.19 \mathrm{ppm}$ (2H, triple-triplet appearing as a quintet), $2.99 \mathrm{ppm}$ ( $3 \mathrm{H}$, singlet), $3.58 \mathrm{ppm}$ (2H, triplet, $J=7.4 \mathrm{~Hz}$ ), 4.08 ppm (2H, triplet, $J=6.1 \mathrm{~Hz}), 6.36 \mathrm{ppm}(1 \mathrm{H}$, doublet, $J=16.0 \mathrm{~Hz}), 7.59$ ppm (1H, doublet, $J=16.0 \mathrm{~Hz}$ ), $7.62 \mathrm{ppm}(1 \mathrm{H}$, doublet, $J=7.1 \mathrm{~Hz}), 7.66 \mathrm{ppm}(2 \mathrm{H}$, singlet), $7.70 \mathrm{ppm}$ ( $2 \mathrm{H}$, two overlapping double-doublets appearing as a multiplet), $8.02 \mathrm{ppm}(1 \mathrm{H}$, doublet, $J=7.1 \mathrm{~Hz}) .{ }^{13} \mathbf{C}-\mathbf{N M R}\left(\mathbf{C D C l}_{3}, \mathbf{7 7 . 0}\right.$ ppm): $\delta 28.55$ ppm, 34.76 ppm, 47.45 ppm, 70.90 ppm, 118.52 ppm, 118.87 ppm, 124.11 ppm, 130.90 ppm, 131.55 ppm, 132.33 ppm, 132.53 ppm, 133.55 ppm, 138.98 ppm, 143.65 ppm, 148.20 ppm, 154.80 ppm, 171.60 ppm. MS (ESI): $m / z(\mathrm{M}+\mathrm{H})^{+}$-found: 576.90, $(\mathrm{M}+\mathrm{H})^{+}$-calculated: 576.93.

\section{3-Bromopropyl-carbamic acid tert-butyl ester.}

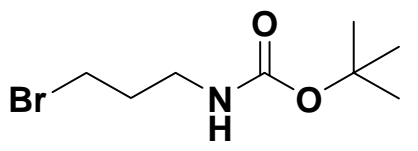

Procedure: A round-bottom flask was charged with $5.47 \mathrm{~g}$ (25 mmol) of 3bromo-propylamine hydrobromide. $40 \mathrm{~mL}$ of $\mathrm{CH}_{2} \mathrm{Cl}_{2}$ were added to dissolve the solid, followed by $8.36 \mathrm{~mL}$ ( $60 \mathrm{mmol}, 2.4$ equiv.) of triethylamine. After stirring for 5 mins at room temperature, $6.55 \mathrm{~g}$ (30 mmol, 1.2 equiv.) of $\mathrm{Boc}_{2} \mathrm{O}$ in $20 \mathrm{~mL} \mathrm{CH}_{2} \mathrm{Cl}_{2}$ were added and the reaction was allowed to proceed 
for $16 \mathrm{~h}$ under argon. The reaction mixture was then washed once with $1 \mathrm{M}$ aqueous $\mathrm{HCl}$, once with aqueous $\mathrm{NaCl}$ (sat.) and once with $\mathrm{H}_{2} \mathrm{O}$. After drying the organic phase over $\mathrm{MgSO}_{4}$, the $\mathrm{CH}_{2} \mathrm{Cl}_{2}$ was removed under vacuum to provide a viscous yellowish oil. Extensive drying of the oil on a lyophilizer gave $5.23 \mathrm{~g}$ (22 mmol, 88\%) of Boc-protected 3-bromopropylamine as a white solid. ${ }^{1} \mathbf{H}$-NMR $\left(\mathbf{C D C l}_{3}, \mathbf{7 . 2 6} \mathbf{~ p p m}\right): \delta 1.43 \mathrm{ppm}$ (9H, singlet), $2.04 \mathrm{ppm}$ (2H, triple-triplet appearing as a quintet), $3.27 \mathrm{ppm}$ ( $2 \mathrm{H}$, triplet, $J=5.8 \mathrm{~Hz}$ ), $3.43 \mathrm{ppm}(2 \mathrm{H}$, triplet, $J=6.5 \mathrm{~Hz}) .{ }^{13} \mathbf{C}-\mathbf{N M R}\left(\mathbf{C D C l}_{3}\right.$, 77.0 ppm): $\delta 28.20$ ppm, 30.58 ppm, 32.53 ppm, 38.83 ppm, 78.82 ppm, 155.86 ppm. MS (ESI): $m / z(M+H)^{+}$-found: 238.02, $(\mathbf{M}+\mathrm{H})^{+}$-calculated: 238.05 .

\section{[3-(2,6-Dibromo-4-iodophenoxy)-propyl]-carbamic acid tert-butyl ester} (14).

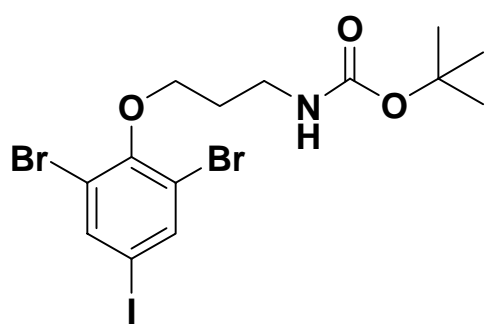

Procedure: A round-bottom flask was charged with $1.88 \mathrm{~g}$ (5 mmol) of 7, 1.55 g (6.5 mmol, 1.3 equiv.) of Boc-protected 3-bromo-propylamine, $2.44 \mathrm{~g}$ (7.5 mmol, 1.5 equiv.) of $\mathrm{Cs}_{2} \mathrm{CO}_{3}$ and $0.19 \mathrm{~g}$ (1.25 mmol, 0.25 equiv.) of NaI. $40 \mathrm{~mL}$ of $\mathrm{CH}_{3} \mathrm{CN}$ were added and the mixture was stirred at $65^{\circ} \mathrm{C}$ for 8 $\mathrm{h}$ under argon. It was then cooled and filtered and the solvent was removed under vacuum. The crude product was redissolved in a small amount of ethyl ether, applied to a silica column and eluted with 4:1 v/v hexane-ethyl ether. Purification afforded 2.57 g (4.8 mmol, 96\%) of $\mathbf{1 4}$ as a white solid. ${ }^{\mathbf{1}} \mathbf{H}$ - 
NMR (CDCl 3 , $7.26 \mathbf{p p m}): \delta 1.45$ ppm (9H, singlet), 2.04 ppm (2H, tripletriplet appearing as a quintet), $3.43 \mathrm{ppm}(2 \mathrm{H}$, broad singlet), $4.04 \mathrm{ppm}(2 \mathrm{H}$, triplet, $J=5.9 \mathrm{~Hz}$ ), $4.88 \mathrm{ppm}\left(1 \mathrm{H}\right.$, broad singlet), $7.81 \mathrm{ppm}\left(2 \mathrm{H}\right.$, singlet). ${ }^{13} \mathrm{C}$ NMR (CDCl $\mathbf{3}, \mathbf{7 7 . 0} \mathbf{p p m}): \delta 28.43$ ppm, 30.34 ppm, 37.94 ppm, 71.37 ppm, 78.68 ppm, 87.66 ppm, 119.28 ppm, 140.70 ppm, 155.98 ppm, 157.69 ppm. MS (ESI): $m / z \quad(\mathrm{M}-\mathrm{Boc}+2 \mathrm{H})^{+}$-found: 433.86, $(\mathrm{M}-\mathrm{Boc}+2 \mathrm{H})^{+}$-calculated: 433.83 .

\section{[3-(2,6-Dibromo-4-trimethylsilanylethynyl-phenoxy)-propyl]-carbamic acid tert-butyl ester (15).}

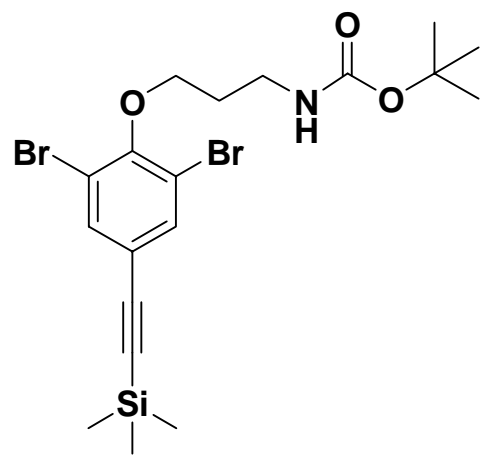

Procedure: A round-bottom flask was charged with $1.605 \mathrm{~g}$ ( $3 \mathrm{mmol}$ ) of 14, $0.14 \mathrm{~g}$ (0.12 mmol, 0.04 equiv.) of $\mathrm{Pd}\left(\mathrm{Ph}_{3} \mathrm{P}\right)_{4}$ and $0.046 \mathrm{~g}(0.24 \mathrm{mmol}, 0.08$ equiv.) of CuI. $50 \mathrm{~mL}$ of triethylamine were added to dissolve the solids, followed by $0.58 \mathrm{~mL}$ ( $4.2 \mathrm{mmol}$, 1.4 equiv.) of ethynyl-trimethylsilane. Reaction was vigorously stirred under argon and in the dark for $4 \mathrm{~h}$ at room temperature. Most of the TEA was then removed under vacuum and the solid residue was redissolved in ethyl ether and washed once with aqueous $\mathrm{CuSO}_{4}$ (sat.), once with aqueous $\mathrm{NaCl}$ (sat.) and once with $\mathrm{H}_{2} \mathrm{O}$. After drying over $\mathrm{MgSO}_{4}$, the organic phase was concentrated under vacuum and applied to a silica column. A 4:1 v/v hexane-ethyl ether mixture was used for elution. Purification yielded $1.36 \mathrm{~g}$ (2.7 mmol, 90\%) of 15 as a white 
solid. ${ }^{1} \mathbf{H}$-NMR ( $\mathbf{C D C l}_{3}, \mathbf{7 . 2 6} \mathbf{~ p p m ) : ~} \delta 0.26 \mathrm{ppm}$ (9H, singlet), $1.45 \mathrm{ppm}$ (9H, singlet), $2.04 \mathrm{ppm}$ (2H, triple-triplet appearing as a quintet), $3.43 \mathrm{ppm}$ (2H, broad singlet), $4.04 \mathrm{ppm}(2 \mathrm{H}$, triplet, $J=6.1 \mathrm{~Hz}), 4.89 \mathrm{ppm}(1 \mathrm{H}$, broad singlet), $7.62 \mathrm{ppm}$ (2H, singlet). ${ }^{13} \mathbf{C}-\mathbf{N M R}\left(\mathbf{C D C l}_{3}, \mathbf{7 7 . 0} \mathbf{~ p p m}\right): \delta-0.23$ ppm, 28.44 ppm, 30.07 ppm, 37.87 ppm, 71.44 ppm, 78.97 ppm, 96.68 ppm, 101.36 ppm, 117.83 ppm, 121.65 ppm, 135.87 ppm, 153.40 ppm, 156.00 ppm. MS (ESI): $m / z \quad(\mathrm{M}-\mathrm{Boc}+2 \mathrm{H})^{+}$-found: 404.00, $\quad(\mathrm{M}-\mathrm{Boc}+2 \mathrm{H})^{+}-$ calculated: 403.97.

[3-(2,6-Dibromo-4-bromoethynyl-phenoxy)-propyl]-carbamic acid tertbutyl ester (16).

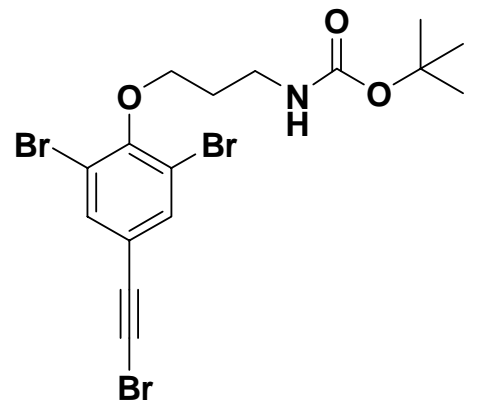

Procedure: A round-bottom flask was charged with $1.01 \mathrm{~g}$ (2 mmol) of 15 and $0.10 \mathrm{~g}$ ( $0.6 \mathrm{mmol}, 0.3$ equiv.) of $\mathrm{AgNO}_{3} .10 \mathrm{ml}$ of acetone were added and the mixture was cooled at $0{ }^{\circ} \mathrm{C} .0 .50 \mathrm{~g}$ ( $2.8 \mathrm{mmol}, 1.4$ equiv.) of NBS in $10 \mathrm{ml}$ of acetone were added dropwise over a period of 15-30 mins. Subsequently the reaction was allowed to warm up to room temperature and stirring continued for $1.5 \mathrm{~h}$ under argon. The mixture was then concentrated under vacuum and directly applied to a silica column. It was eluted with 3:1 v/v hexane-ethyl acetate. Purification afforded $0.93 \mathrm{~g}$ (1.82 mmol, 91\%) of 16 as a beige solid. ${ }^{\mathbf{1}} \mathbf{H}$-NMR ( $\mathbf{C D C l}_{3}, \mathbf{7 . 2 6} \mathbf{~ p p m ) : ~} \delta 1.45 \mathrm{ppm}$ (9H, singlet), $2.04 \mathrm{ppm}(2 \mathrm{H}$, triple-triplet appearing as a quintet), $3.44 \mathrm{ppm}(2 \mathrm{H}$, broad 
singlet), $4.05 \mathrm{ppm}$ ( $2 \mathrm{H}$, triplet, $J=5.8 \mathrm{~Hz}$ ), $4.88 \mathrm{ppm}$ (1H, broad singlet), 7.59

ppm (2H, singlet). ${ }^{13} \mathbf{C}-\mathbf{N M R}$ (CDCl $\mathbf{3}, \mathbf{7 7 . 0} \mathbf{~ p p m ) : ~} \delta 28.44$ ppm, $30.07 \mathrm{ppm}$, 37.95 ppm, 52.20 ppm, 71.47 ppm, 76.84 ppm, 79.23 ppm, 118.05 ppm, 121.25 ppm, 135.96 ppm, 153.72 ppm, 156.11 ppm. MS (ESI): m/z (MBoc $+2 \mathrm{H})^{+}$-found: 409.82, $(\mathrm{M}-\mathrm{Boc}+2 \mathrm{H})^{+}$-calculated: 409.84 .

\section{\{3-[2,6-Dibromo-4-(2-dimethylamino-ethyl)-phenoxy]-propyl\}-carbamic acid tert-butyl ester (17).}

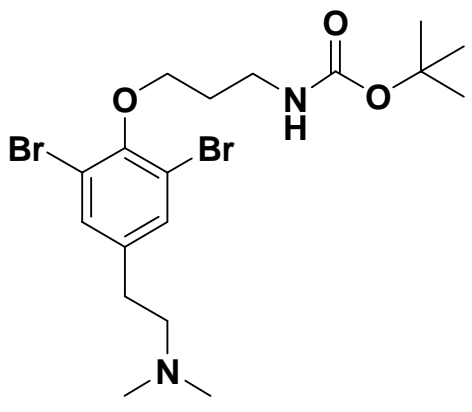

Procedure: a) Aminolysis step. A flask was charged with $0.77 \mathrm{~g}$ (1.5 mmol) of 16. The solid was dissolved in $7.5 \mathrm{~mL}$ of a $2 \mathrm{M}$ dimethylamine solution in THF (15 mmol, 10 equiv.) and $1.40 \mathrm{~mL}$ of acetonitrile. The reaction mixture was vigorously agitated under argon for $3 \mathrm{~h}$ at room temperature on a shaker. At that point LC-MS showed complete consumption of 16. b) Reduction step. The above mixture was cooled to $0{ }^{\circ} \mathrm{C}$ and $0.28 \mathrm{~g}$ (7.5 mmol, 5 equiv.) of $\mathrm{NaBH}_{4}$, dissolved in $7.5 \mathrm{~mL}$ of ice-cold $\mathrm{CH}_{3} \mathrm{OH}$, was syringed in. The reaction was allowed to proceed at $0{ }^{\circ} \mathrm{C}$ for 30 mins. The solvent was subsequently removed under vacuum and the residue was redissolved in a small amount of $\mathrm{CH}_{3} \mathrm{OH}$, applied to a silica column and eluted with 9:1 v/v $\mathrm{CH}_{2} \mathrm{Cl}_{2}-\mathrm{CH}_{3} \mathrm{OH}$. Purification afforded $0.56 \mathrm{~g}$ (1.17 mmol, 78\%) of 17 as a white solid. ${ }^{1} \mathbf{H}-\mathbf{N M R}$ (CD $\left.\mathbf{C D}_{3} \mathbf{O D}, 3.31 \mathbf{p p m}\right): \delta 1.44$ ppm (9H, singlet), $2.01 \mathrm{ppm}$ (2H, triplet-triplet appearing as a quintet), 2.35 
ppm (6H, singlet), $2.61 \mathrm{ppm}(2 \mathrm{H}$, triplet, $J=7.8 \mathrm{~Hz}), 2.76 \mathrm{ppm}(2 \mathrm{H}$, triplet, $J=7.8 \mathrm{~Hz}$ ), $3.27 \mathrm{ppm}$ (2H, triplet, $J=6.8 \mathrm{~Hz}$ ), $4.02 \mathrm{ppm}$ (2H, triplet, $J=6.1$ $\mathrm{Hz}$ ), 7.47 ppm (2H, singlet). ${ }^{13} \mathbf{C}-\mathbf{N M R}$ (CD $\mathbf{C D}_{3} \mathbf{O D}, 49.05$ ppm): $\delta 27.86$ ppm, 28.86 ppm, 31.03 ppm, 38.72 ppm, 44.33 ppm, 60.02 ppm, 72.42 ppm, 79.98 ppm, 119.19 ppm, 134.35 ppm, 138.26 ppm, 153.37 ppm, 156.20 ppm. MS (ESI): $m / z(\mathrm{M}+\mathrm{H})^{+}$-found: 479.03, $(\mathrm{M}+\mathrm{H})^{+}$-calculated: 479.06.

\section{3-[2,6-Dibromo-4-(2-dimethylamino-ethyl)-phenoxy]-propylamine}

\section{dihydrochloride (5).}

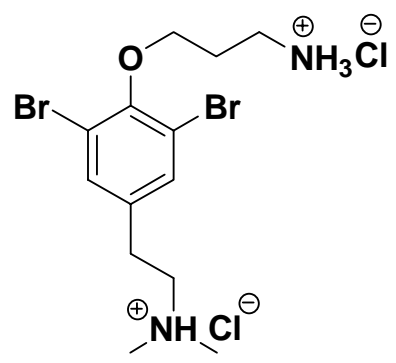

Procedure: A flask was charged with $0.250 \mathrm{~g}$ of 17 (0.52 mmol). $10.4 \mathrm{~mL}$ of a 4M HCl solution in dioxane (41.6 mmol, 80 equiv.) were added and the mixture was stirred first at $0{ }^{\circ} \mathrm{C}$ for 10 mins and then at room temperature for 20 mins. The solvent was subsequently removed under vacuum and the residue was extensively dried on a lyophilizer. 0.235 g (0.52 mmol, 100\%) of dihydrochloride salt 5 were obtained as a white solid and shown to be pure by LC-MS and NMR. ${ }^{1} \mathbf{H}-\mathbf{N M R}$ (CD $\left.\mathbf{C D}_{3} \mathbf{O D}, 3.31 \mathbf{p p m}\right): \delta 2.22 \mathrm{ppm}(2 \mathrm{H}$, triple-triplet appearing as a quintet), $2.94 \mathrm{ppm}(6 \mathrm{H}$, singlet), $3.05 \mathrm{ppm}(2 \mathrm{H}$, triplet, $J=8.3 \mathrm{~Hz}$ ), $3.30 \mathrm{ppm}(2 \mathrm{H}$, triplet, $J=7.5 \mathrm{~Hz}), 3.37 \mathrm{ppm}(2 \mathrm{H}$, triplet, $J=8.3 \mathrm{~Hz}$ ), $4.12 \mathrm{ppm}$ (2H, triplet, $J=5.7 \mathrm{~Hz}$ ), $7.63 \mathrm{ppm}\left(2 \mathrm{H}\right.$, singlet). ${ }^{13} \mathbf{C}$ NMR (CD $\mathbf{3}$ OD, 49.05 ppm): $\delta 29.10$ ppm, 30.35 ppm, 38.94 ppm, 43.68 ppm, 59.19 ppm, 71.74 ppm, 119.34 ppm, 134.60 ppm, 137.14 ppm, 154.87 
ppm. MS (ESI): $\quad m / z \quad(\mathrm{M}-2 \mathrm{HCl}+\mathrm{H})^{+}$-found: 379.03, $\quad(\mathrm{M}-2 \mathrm{HCl}+\mathrm{H})^{+}-$ calculated: 379.00 .

\section{\{3-[2,6-Dibromo-4-(2,2-bis(dimethylamine)-vinyl)-phenoxy]-propyl\}- carbamic acid tert-butyl ester (19).}

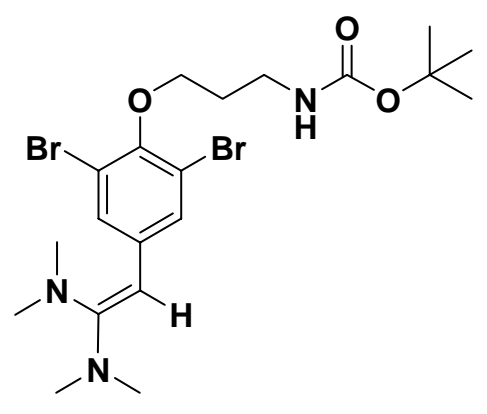

Procedure: Preparation of $\mathbf{1 9}$ same as aminolysis step in preparation of $\mathbf{1 7}$ above. By completely removing the solvent under vacuum following aminolysis, redissolving the residue in a small amount of $\mathrm{CH}_{3} \mathrm{OH}$, applying to a silica column and eluting with $4: 1 \mathrm{v} / \mathrm{v} \mathrm{CH}_{2} \mathrm{Cl}_{2}-\mathrm{CH}_{3} \mathrm{OH}$, intermediate 19 was isolated as a white solid. The yield was roughly equal to the yield for the 2-step transformation of $\mathbf{1 6}$ to $\mathbf{1 7}\left(\mathrm{NaBH}_{4}\right.$ reduction of $\mathbf{1 9}$ is quantitative). ${ }^{\mathbf{1}} \mathbf{H}-\mathbf{N M R}$ (CDCl $\mathbf{3}, \mathbf{7 . 2 6} \mathbf{~ p p m ) : ~} 1.44 \mathrm{ppm}$ (9H, singlet), 2.04 ppm ( $2 \mathrm{H}$, triple-triplet appearing as a quintet), $3.37 \mathrm{ppm}(12 \mathrm{H}$, singlet), 3.40 ppm (2H, triplet, $J=7.5 \mathrm{~Hz}$ ), 4.05 ppm (2H, triplet, $J=5.8 \mathrm{~Hz}), 4.44 \mathrm{ppm}(1 \mathrm{H}$, singlet), 7.25 ppm (2H, singlet). ${ }^{1} \mathbf{H}-\mathbf{N M R}$ (CD $\left.\mathbf{C D}_{\mathbf{3}} \mathbf{O D}, \mathbf{3 1} \mathbf{3 p m}\right): \delta 1.44 \mathrm{ppm}$ (9H, singlet), $2.03 \mathrm{ppm}$ (2H, triple-triplet appearing as a quintet), $3.27 \mathrm{ppm}$ (12H, broad singlet), $3.33 \mathrm{ppm}(2 \mathrm{H}$, triplet, $J=7.5 \mathrm{~Hz}$ ), $4.06 \mathrm{ppm}$ (2H, triplet, $J=6.1 \mathrm{~Hz}$ ), $7.44 \mathrm{ppm}$ (2H, singlet). ${ }^{13} \mathbf{C}-\mathbf{N M R}$ (CD $\mathbf{C D}_{3} \mathbf{O D}, 49.05$ ppm): $\delta 28.87$ ppm, 31.49 ppm, 38.56 ppm, 43.65 ppm, 72.36 ppm, 72.82 ppm, 79.97 ppm, 120.24 ppm, 131.47 ppm, 133.05 ppm, 155.10 ppm, 158.36 ppm, 161.03 ppm. MS (ESI): $m / z(\mathrm{M}+\mathrm{H})^{+}$-found: 520.05, $(\mathrm{M}+\mathrm{H})^{+}$-calculated: 520.08. 
(E)-N-\{3-[2,6-dibromo-4-(2-dimethylamino-ethyl)-phenoxy]-propyl\}-3[3,5-dibromo-4-(3-dimethylamino-propoxy)-phenyl]-acrylamide (1).

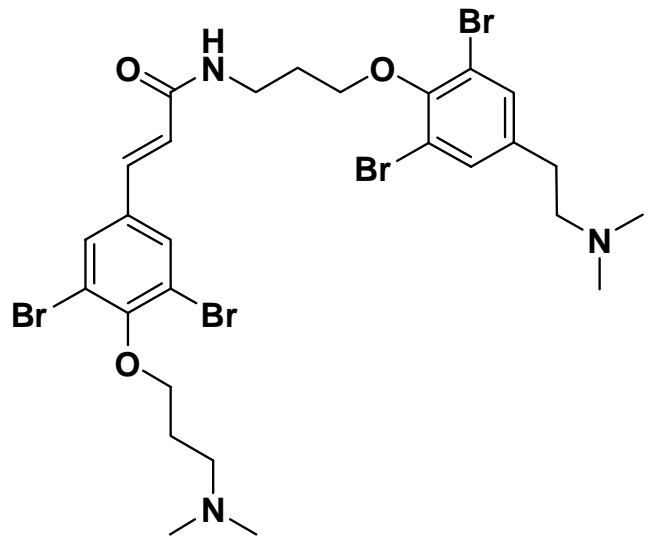

Procedure: A flask was charged with $0.061 \mathrm{~g}(0.15 \mathrm{mmol})$ of $3.2 \mathrm{~mL}$ of THF were added, followed by $0.105 \mathrm{~mL}$ (0.75 mmol, 5 equiv.) of triethylamine. After 5 mins of stirring at room temperature, $0.027 \mathrm{~mL}(0.18$ mmol, 1.2 equiv.) of DEPC dissolved in $1 \mathrm{~mL}$ THF were added and the mixture was stirred for 5 more minutes. Finally, 0.068 g $(0.15 \mathrm{mmol}, 1$ equiv.) of 5 were added in solid form and the reaction was allowed to proceed for $2 \mathrm{~h}$. The solvent was then removed under vacuum, the residue redissolved in a small amount of methanol, applied to a silica column and eluted with 9:1 v/v $\mathrm{CH}_{2} \mathrm{Cl}_{2}-\mathrm{CH}_{3} \mathrm{OH}$, modified with $0.5 \%$ triethylamine. Purification afforded $0.103 \mathrm{~g}$ (0.134 mmol, 89\%) of psammaplysene A (1) as a colorless solid. ${ }^{1} \mathbf{H}-\mathbf{N M R}\left(\mathbf{C D}_{3} \mathbf{O D}, 3.31 \mathbf{p p m}\right): \delta 2.07 \mathrm{ppm}(2 \mathrm{H}$, tripletriplet appearing as a quintet), $2.12 \mathrm{ppm}(2 \mathrm{H}$, triple-triplet appearing as a quintet), $2.29 \mathrm{ppm}$ (6H, singlet), $2.31 \mathrm{ppm}$ (6H, singlet), $2.54 \mathrm{ppm}(2 \mathrm{H}$, triplet, $J=7.8 \mathrm{~Hz}$ ), $2.66 \mathrm{ppm}(2 \mathrm{H}$, triplet, $J=7.8 \mathrm{~Hz}), 2.74 \mathrm{ppm}(2 \mathrm{H}$, triplet, $J=7.8 \mathrm{~Hz}$ ), $3.59 \mathrm{ppm}$ (2H, triplet, $J=6.9 \mathrm{~Hz}$ ), $4.07 \mathrm{ppm}$ (4H, two overlapping triplets appearing as a multiplet, $J=6.4 \mathrm{~Hz}$ for both), $6.59 \mathrm{ppm}(1 \mathrm{H}$, doublet, $J=15.7 \mathrm{~Hz}$ ), $7.39 \mathrm{ppm}(1 \mathrm{H}$, doublet, $J=15.7 \mathrm{~Hz}), 7.46 \mathrm{ppm}$ (2H, singlet), 
$7.80 \mathrm{ppm}$ (2H, singlet). ${ }^{13} \mathbf{C}-\mathbf{N M R}\left(\mathbf{C D}_{3} \mathbf{O D}, 49.05 \mathbf{p p m}\right): \delta 29.00 \mathrm{ppm}$, $30.82 \mathrm{ppm}, 33.24 \mathrm{ppm}, 38.10 \mathrm{ppm}, 45.37 \mathrm{ppm}$ (all sets of methyl carbons overlapping), 57.46 ppm, 61.68 ppm, 72.21 ppm, 72.95 ppm, 119.03 ppm, 119.71 ppm, 124.16 ppm, 132.27 ppm, 133.08 ppm, 134.16 ppm, 138.13 ppm, 140.67 ppm, 153.11 ppm, 155.10 ppm, 167.96 ppm. MS (ESI): $\mathrm{m} / \mathrm{z}$ $(\mathrm{M}+\mathrm{H})^{+}$-found: 765.98, $(\mathrm{M}+\mathrm{H})^{+}$-calculated: 765.95 .

(E)- $N$-\{3-[2,6-dibromo-4-(2-dimethylamino-ethyl)-phenoxy]-propyl\}-3\{3,5-dibromo-4-[3-( $N$-methyl-2-nitrophenylsulfonamido)-propoxy]phenyl\}-acrylamide (20).

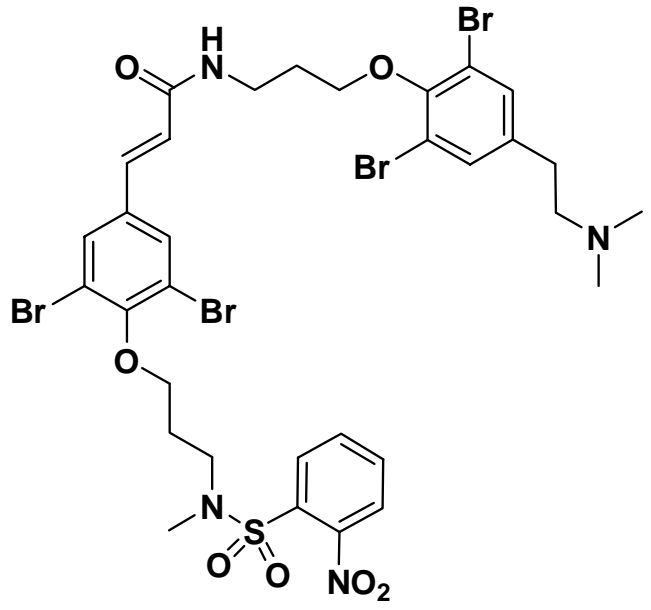

Procedure: A flask was charged with $0.102 \mathrm{~g}(0.25 \mathrm{mmol})$ of $13.4 \mathrm{~mL}$ of THF were added, followed by $0.17 \mathrm{~mL}(1.25 \mathrm{mmol}, 5$ equiv. $)$ of triethylamine. After 5 mins of stirring at room temperature, $0.045 \mathrm{~mL}(0.30$ mmol, 1.2 equiv.) of DEPC dissolved in $1 \mathrm{~mL}$ THF were added and the mixture was stirred for 5 more minutes. Finally, $0.113 \mathrm{~g}(0.25 \mathrm{mmol}, 1$ equiv.) of $\mathbf{5}$ were added in a solid form and the reaction was allowed to proceed for $2 \mathrm{~h}$. The solvent was then removed under vacuum, the residue redissolved in a small amount of methanol, applied to a silica column and eluted with 9:1 v/v $\mathrm{CH}_{2} \mathrm{Cl}_{2}-\mathrm{CH}_{3} \mathrm{OH}$. Purification afforded $0.205 \mathrm{~g}(0.22$ 
mmol, $88 \%)$ of 20 as a white solid. ${ }^{1} \mathbf{H}-\mathbf{N M R}\left(\mathbf{C D C l}_{3}, \mathbf{7 . 2 6} \mathbf{p p m}\right): \delta 2.12$ ppm (2H, triple-triplet appearing as a quintet), $2.17 \mathrm{ppm}(2 \mathrm{H}$, triple-triplet appearing as a quintet), $2.36 \mathrm{ppm}(6 \mathrm{H}$, singlet), $2.60 \mathrm{ppm}(2 \mathrm{H}$, broad singlet), 2.77 ppm (2H, broad singlet), 2.99 ppm (3H, singlet), 3.57 ppm ( $2 \mathrm{H}$, triplet, $J=7.4 \mathrm{~Hz}$ ), $3.73 \mathrm{ppm}$ ( $2 \mathrm{H}$, double-triplet appearing as a quartet), 4.07 ppm (2H, triplet, $J=6.1 \mathrm{~Hz}$ ), 4.12 ppm (2H, triplet, $J=5.4 \mathrm{~Hz}$ ), $6.31 \mathrm{ppm}$ $(1 \mathrm{H}$, doublet, $J=15.7 \mathrm{~Hz}), 6.41(1 \mathrm{H}$, triplet, $J=5.2 \mathrm{~Hz}), 7.38 \mathrm{ppm}(2 \mathrm{H}$, singlet), $7.44 \mathrm{ppm}(1 \mathrm{H}$, doublet, $J=15.7 \mathrm{~Hz}$ ), $7.45 \mathrm{ppm}(1 \mathrm{H}$, doublet, $J=6.8$ $\mathrm{Hz}$ ), $7.62 \mathrm{ppm}$ (2H, singlet), $7.69 \mathrm{ppm}$ (2H, two overlapping doubledoublets appearing as a multiplet), $8.02 \mathrm{ppm}(1 \mathrm{H}$, doublet, $J=6.8 \mathrm{~Hz}) .{ }^{13} \mathbf{C}$ NMR (CDCl 3 , 77.0 ppm): $\delta 28.59$ ppm, 29.25 ppm, 32.68 ppm, 34.81 ppm, 38.16 ppm, 45.24 ppm, 47.49 ppm, 60.57 ppm, 70.77 ppm, 72.36 ppm, 117.95 ppm, 118.69 ppm, 122.96 ppm, 124.09 ppm, 130.61 ppm, 130.95 ppm, 131.50 ppm, 131.72 ppm, 131.84 ppm, 133.47 ppm, 133.57 ppm, 137.25 ppm, 144.26 ppm, 148.20 ppm, 153.72 ppm, 154.87 ppm, 164.92 ppm. MS (ESI): $m / z(\mathrm{M}+\mathrm{H})^{+}$-found: 936.89, $(\mathrm{M}+\mathrm{H})^{+}$-calculated: 936.91.

(E)-N-\{3-[2,6-dibromo-4-(2-dimethylamino-ethyl)-phenoxy]-propyl\}-3[3,5-dibromo-4-(3-methylamino-propoxy)-phenyl]-acrylamide (2).

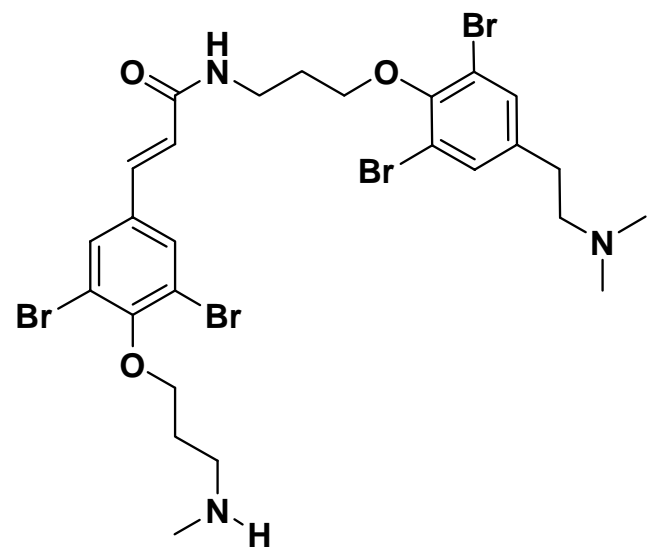


Procedure: A flask was charged with $0.10 \mathrm{~g}(0.11 \mathrm{mmol})$ of 20 and $0.11 \mathrm{~g}$ (0.33 mmol, 3 equiv.) of $\mathrm{Cs}_{2} \mathrm{CO}_{3} .3 .5 \mathrm{~mL}$ of acetonitrile were added, followed by $0.012 \mathrm{~mL}$ (0.12 mmol, 1.1 equiv.) of thiophenol. The mixture was stirred at room temperature for $1.5 \mathrm{~h}$. It was then concentrated under vacuum and directly applied to a silica column. Elution with $\mathrm{CH}_{2} \mathrm{Cl}_{2^{-}}$ $\mathrm{CH}_{3} \mathrm{OH}$ solvent systems, starting with $4: 1 \mathrm{v} / \mathrm{v}$ and ending with $3: 2 \mathrm{v} / \mathrm{v}$, all modified with $0.5 \%$ triethylamine, provided $0.072 \mathrm{~g}(0.095 \mathrm{mmol}, 86 \%)$ of psammaplysene B (2) as a colorless solid. ${ }^{1} \mathrm{H}-\mathrm{NMR}$ ( $\left.\mathrm{CD}_{3} \mathrm{OD}, 3.31 \mathrm{ppm}\right): \delta$ $2.11 \mathrm{ppm}(2 \mathrm{H}$, triple-triplet appearing as a quintet), $2.29 \mathrm{ppm}(2 \mathrm{H}$, tripletriplet appearing as a quintet), $2.78 \mathrm{ppm}(3 \mathrm{H}$, singlet), $2.90 \mathrm{ppm}(6 \mathrm{H}$, singlet), $3.07 \mathrm{ppm}$ (2H, triplet, $J=8.6 \mathrm{~Hz}$ ), $3.27 \mathrm{ppm}$ (2H, triplet, $J=8.6 \mathrm{~Hz}$ ), 3.36 ppm (2H, triplet, $J=7.5 \mathrm{~Hz}$ ), 3.59 ppm (2H, triplet, $J=7.0 \mathrm{~Hz}$ ), 4.03 ppm (2H, triplet, $J=5.9 \mathrm{~Hz}), 4.12 \mathrm{ppm}(2 \mathrm{H}$, triplet, $J=5.6 \mathrm{~Hz}), 6.61 \mathrm{ppm}(1 \mathrm{H}$, doublet, $J=15.7 \mathrm{~Hz}), 7.38$ ppm $(1 \mathrm{H}$, doublet, $J=15.7 \mathrm{~Hz}), 7.58 \mathrm{ppm}(2 \mathrm{H}$, singlet), 7.77 ppm (2H, singlet). ${ }^{13}$ C-NMR (CD $\mathbf{O}$ OD, 49.05 ppm): $\delta 29.89$ ppm, 30.52 ppm, 33.14 ppm, 36.20 ppm, 38.13 ppm, 45.30 ppm, 49.29 ppm, 60.48 ppm, 72.16 ppm, 72.86 ppm, 118.83 ppm, 119.46 ppm, 123.93 ppm, 132.17 ppm, 132.98 ppm, 134.12 ppm, 137.96 ppm, 141.01 ppm, 153.11 ppm, 154.90 ppm, 165.02 ppm. MS (ESI): $m / z(M+H)^{+}$-found: 751.97. $(\mathrm{M}+\mathrm{H})^{+}$-calculated: 751.94 . 


\section{${ }^{1} \mathrm{H}$-NMR spectra of psammaplysenes A and B:}

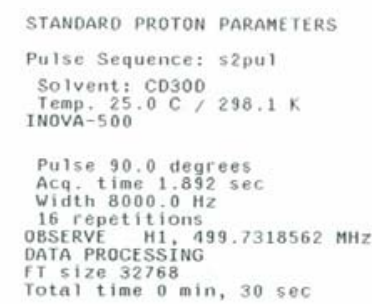

STANDARO PROTON PARAMETERS

Pulse Sequence: 52 pul

Solvent: $\operatorname{CD} 0300$

Pulse 90.0 degrees

Width $8000.0 \mathrm{~Hz}$

rotal time $0 \mathrm{~min}, 30 \mathrm{sec}$

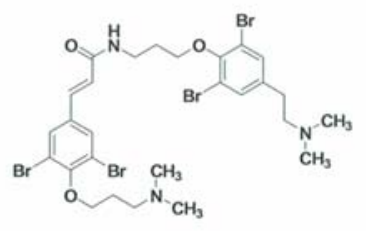

(1, basic conditions)

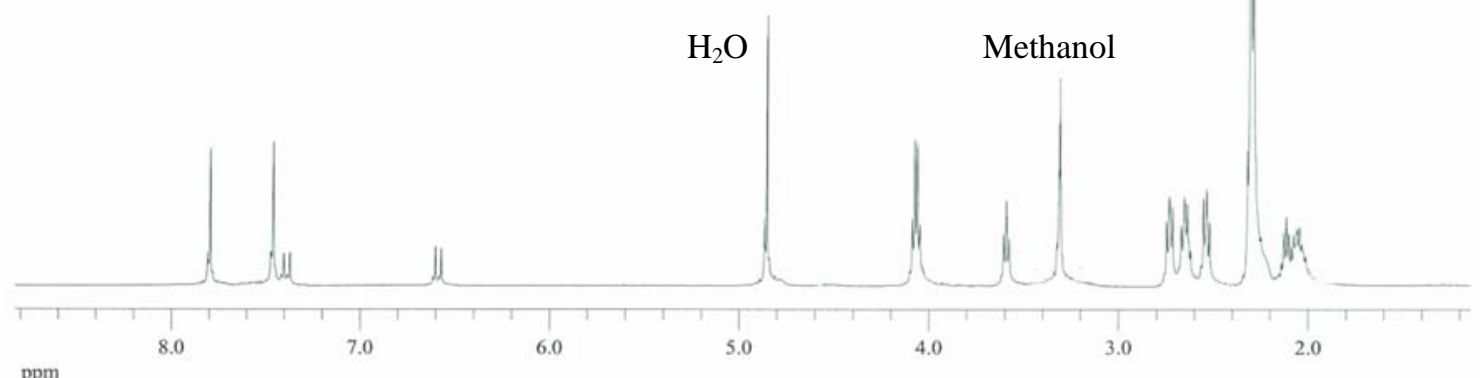

ppm

STANDARD PROTON PARAMETERS

Pulse Sequence: s2pur

Solvent: C0300

Temp. 25.0 C, $298.1 \mathrm{~K}$

Pulse 90,0 degrees

Acq. time 1.892 sec

16 .

OBSERVE H4 499.7318582 MHz

DATA PROCESSINO

FT size 32768

Total time 0 min, 30 sec
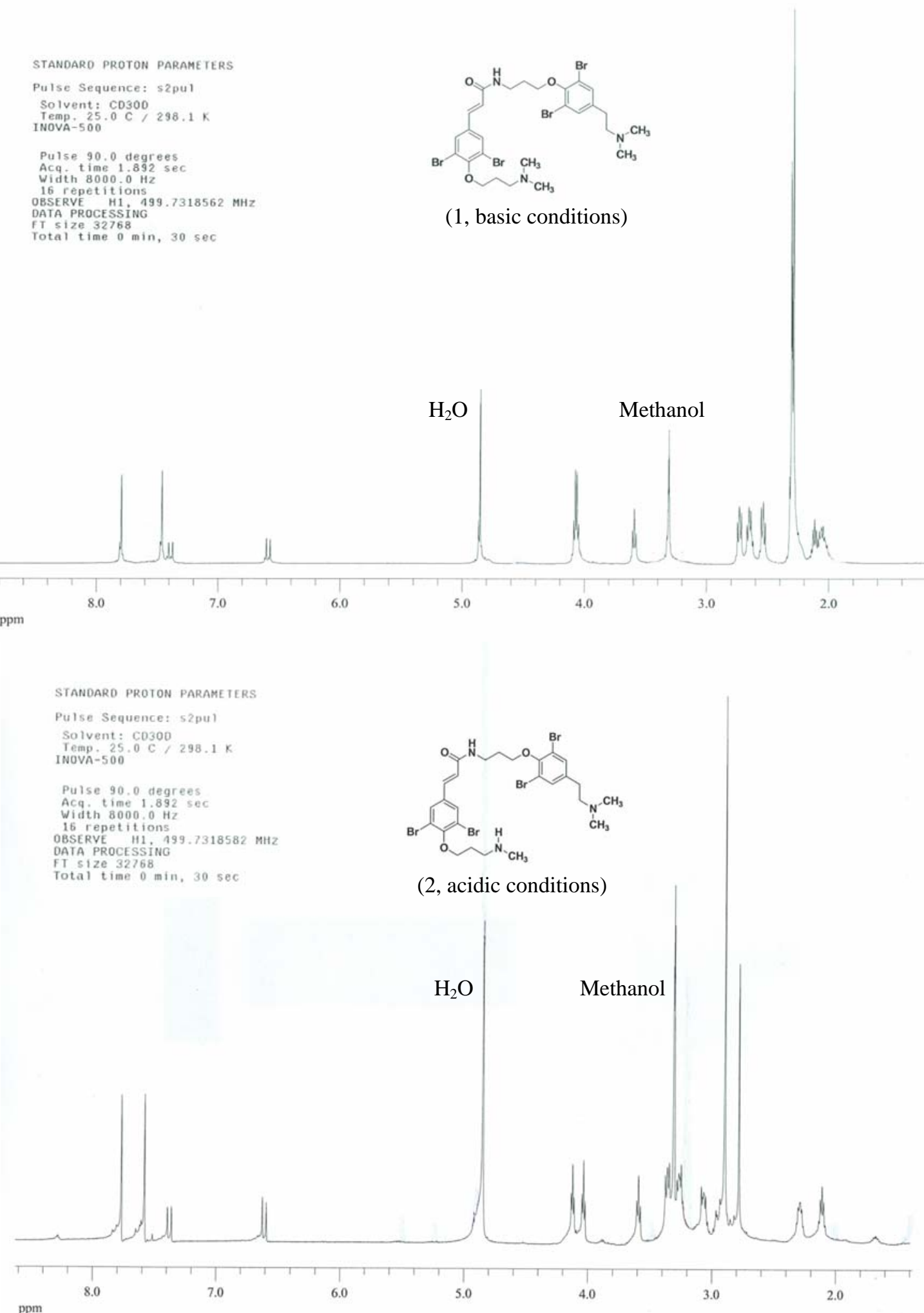

S-23 